\title{
Polysemy in language and thought
}

\begin{abstract}
This paper focuses on the present state of investigation into polysemy, taking into account drawbacks of the existing definitions of this phenomenon. It was found that in Polish and Russian linguistic manuals and encyclopaedias, polysemy as a phenomenon is equalled with a quality for which a new term - polysemantism may be suggested. A brief survey of some of the existing directions in the research of this phenomenon from the point of view of terminology science, translation, terminography and cognition makes it possible to identify some new types of polysemy. A peculiar character of relations between polysemy and homonymy is shown, three sources of polysemy are indicated and such varieties of polysemy as regular polysemy, hyponymic polysemy and consubstantivety are revealed. In translation we come across interlingual hidden polysemy. The development of terminography leads to discovering artificial polysemy and misleading polysemy which are causes of spoiling quality of both dictionaries and translation. In cognition evolution research anthropolinguistic studies made it possible to discover diachronic hidden polysemy of the early words. There are reasons to believe that the development of cognition is based on and results in eliminating this type of hidden polysemy. The resulting tentative classification of types of polysemy reflects progress in investigating this phenomenon and may be used in further research.
\end{abstract}

Keywords: types of polysemy, terminology, translation, translating dictionaries, evolution of cognition.

\section{Introduction}

Though polysemy has been known for more than 25 centuries, and used as an argument against the theory of words formed by the nature of objects, there are still some unclear points about this phenomenon. In the chapter "Polysemy" in the modern English manual on lexicology we read that "...Despite the apparent simplicity, the concept of polysemy is complex and involves a certain number of problems" (Jackson, Amvela 2007: 69). The authors mention the problems of the difficulty in recognizing polysemy (as opposed to homonymy), transference of meanings and the problem of the number of meanings isolated by different specialists, but there are other problems too. In this paper some of these problems, namely terminological problems of naming and defining polysemy, as well as advances in investigating polysemy in a number of directions, such as terminology science, translation, terminography and cognition are going to be discussed. 


\section{Terminological problems of naming polysemy}

It is well known in terminology science that the state of terminology may influence the rate of growth of knowledge. For example, the term "chemical analysis" introduced by R. Boyle played an important role in the understanding of manipulations with substances as purposeful activities and contributed to establishing chemistry as a science. Even more influence on development of science came with an introduction of a system of terms (which usually presupposes systematising respective concepts). Thus, the introduction of biological nomenclature in the $18^{\text {th }}$ century led to the extraordinary flourishing of biological sciences and stimulated the analogous activities in chemistry. On the other hand, there are many instances of stagnation or complete absence of progress in sciences due to inadequate terminology or absence of the necessary terminology. Such was the case with polysemy - this phenomenon received its name (introduced by M. Breal) only at the end of the $19^{\text {th }}$ century. Since the absence of a name makes analysis of the corresponding concept very difficult this means that for a very long period polysemy was not properly investigated. With introducing the term there appeared possibilities of more detailed research of this phenomenon in the $20^{\text {th }}$ century.

Nowadays there are certain difficulties with defining polysemy in some languages, especially Slavonic, though the notion of polysemy seems to be well-known even outside linguistics. In Polish and Russian linguistic manuals and encyclopedias polysemy is equated with a quality of having several meanings (polysemantism).

In Encyklopedia Jezyka Polskiego [Encyclopedia of the Polish Language] (1994) we read: "polisemia (wieloznaczność) polega na tym, iż jakiś element językowy posiada dwa lub kilka różnych znaczeń" [polysemy (polysemantism) is based on the fact that a certain language element has two or several different meanings; transl. author: S.G.-G.].

According to Encyklopedia Językoznawstwa Ogólnego [Encyclopedia of General Linguistics] (1999) "polisemia or wieloznaczność - posiadanie przez wyrażenie językowe kilku znaczeń [polysemy or polysemantism - the possession by a linguistic expression of several meanings; transl. author: S.G.-G.]”.

Czesław Lachur states that "Wieloznaczność (polisemia) polega na tym, że dany leksem ma kilka (co najmniej dwa - wtedy mówi się o "dwuznaczności” jako przypadku polisemii) dających się wyodrębnić znaczeń (zakresów znaczeniowych), które łącznie dają się podporządkować określonemu pojęciu nadrzędnemu [Polysemantism (polysemy) is based on the fact that a given lexeme has several (at least two - then it is called "ambiguity", a type of polysemy) possible to discriminate between meanings (semantic domains) which collectively might be subordinated to a definite subordinate concept; transl. author: S.G.-G.]" (Lachur 2004: 175).

In Russian manuals and encyclopedias we find the same approach:

"Polysemy - polysemantism of a word, one word having several lexical meanings" (Кондаков 1976; transl. author);

"Polysemy, i.e. 'polysemantism' is a feature of majority of everyday words" (Реформатский 1996: 81; transl. author: S.G.-G.); 
"Polysemy - the presence in one and the same word of several lexical meanings; polysemantism" (Ефремова 2000; transl. author: S.G.-G.);

"Polysemy - polysemantism of a word" (Ганеев 2001: 64; transl. author: S.G.-G.)

"Polysemy ling. polysemantism of a word, the presence of several meanings" (Крысин 2008; transl. author: S.G.-G.);

"Polysemy. In linguistics: the presence of more than one meaning in a word, polysemantism" (Ожегов 2008-2009; transl. author: S.G.-G.)

"Polysemy - polysemantism, multi-variance, that is the presence in a word (language unit, term) of two or more meanings, historically conditioned or inter-related in meaning and origin" (ru.wikipedia.org; transl. author: S.G.-G.).

Equating polysemy with polysemanticism may take the form of simply presenting the two terms as synonyms:

"...relation "one more than to one", one phonetic word in relation to many objects and meanings, i.e. polysemantism of a word. Sometimes the same phenomenon is called by the term polysemy" (Степанов 1975: 20; transl. author: S.G.-G.);

"...the ability of words to have several meanings is called polysemantism, or polysemy" (Фомина 1978: 37; transl. author: S.G.-G.);

"...for the vast majority of words of language polysemantism or polysemy is typical" (Маслов 1987: 102; transl. author: S.G.-G.);

"Polysemy (polysemantism) - the presence in a language unit of more than one - two or more - meanings" (Лингвистический... 1990; transl. author: S.G.-G.).

"Polysemy, polysemantism - the presence of more than one meaning in a word" (Энциклопедия "Русский Язык" 1997; transl. author: S.G.-G.);

"polysemantism of a word, or polysemy - is a presence in one and the same word of several interconnected meanings" (Вендина 2002: 136; transl. author: S.G.-G.);

"polysemantism or polysemy of a word (from Latin poly - «many»+ sema - «sign») - is a presence in a language unit of more than one meaning on condition of semantic relation between them or of transfer of the common or adjacent features of functions from one denotate to another" (Елисеева 2003: 17; transl. author: S.G.-G.);

"...one of the results of development of lexical meaning is polysemantism of a word (polysemy)" (Головин 2005: 62; transl. author: S.G.-G.).

Equating the two terms may also be noticed in descriptions of the phenomenon in question in which these terms are used as synonyms:

"Polysemy - the ability of a word to have more than one meaning.... Polysemantism - is a universal language phenomenon, existing in a vast majority of words of any "living" (modern) language" (Алефиренко 2007: 207, 209; transl. author: S.G.-G.).

Jan Malczewski who defines polysemy as a phenomenon - "Zjawisko polegające na tym, że jeden element językowy ... posiada więcej niż jedno znaczenie" [A phenomenon which is based on the fact that one language element ...has more than one meaning; transl. author: S.G.-G.], presents “wieloznaczność (polysemantism)” as another name for this phenomenon (Malczewski 1993). 
Thus both in Polish and in Russian, polysemy, which is a phenomenon, is equated with "polysemantism" - a quality of having several meanings. It is clearly seen in the form of the two terms - "polisemia (polysemy)" and "wieloznaczność (polysemantism)" that only the first one is formally suitable to name a phenomenon, while the second is proper to name a quality. Confusing phenomena and properties which are different ontological and epistemological categories constitutes an epistemological outrage which unfortunately may be noticed in many basic manuals and encyclopaedias.

In some publications the term "wieloznaczność (polysemantism)" is used to name the phenomenon, i.e. Danuta Butler views “wieloznaczność wyrazów (polysemantism of words)” as a phenomenon (Butler 1987: 132). What is quite surprising is the absence of information on polysemy in some linguistic publications. Thus Władysław Miodunka in a manual of lexicology and lexicography (where polysemy should be given special attention) completely ignores polysemy (Miodunka 1989). The only Polish author who notices the danger of confusing two different concepts is Adam Weinsberg, who differentiates between "polisemia (polysemy)" and "polisemiczność (polysemantism)", suggesting a new appropriate term for the quality (Weinsberg 1983: 42, 45).

Another approach towards this problem (in conformity with the well-known tendency for divergence of meanings of synonyms) might be using the term polisemia (polysemy) for the phenomenon and wieloznaczność (polysemantism) for the quality. This approach is used by A. Ja. Szajkiewicz - "If between several similarly expressed meanings may be established a semantic relation, they are regarded as different meanings of one and the same word. Such a word is called mnogoznaczny (polysemantic), and the phenomenon itself is called polysemy (Шайкевич 2005: 141; transl. author: S.G.-G.). In both cases the authors evade confusing phenomenon and property.

In English publications this problem does not exist, since there is only one term used; the authors of linguistic publications understand polysemy only as a phenomenon (Lyons 1976: 447; McArthur 1992, Koskela and Murphy 2006: 742; Jackson and Amvela 2007). In this case the respective quality is ignored and lacks a name, which may hinder research in this direction. We may suggest a respective name - "polysemanticity" or "polysemantism" (which both exist in English as shown in the Oxford English dictionary).

Quite a separate position is taken by Pius ten Hacken from the Swansea University who firmly rejects the possibility of applying a quantitative approach in exploring polysemy, stating: "I see the entire enterprise of counting the number of senses for a particular word as rather dubious". He is critical of the existing practice of presenting polysemic words in dictionaries by enumerating their meanings. Nevertheless, though sometimes it is quite difficult to separate between close meanings lexicologists and lexicographers still present numerous examples of polysemy, while in the majority of modern defining, translating, educational dictionaries, and dictionaries of synonymy most entries contain several definitions, translations or groups of synonyms. Unfortunately, a hesitant attitude towards the phenomenon of polysemy does not seem to solve this problem.

We may also observe the insufficient state of exploration of polysemy as reflected in failing to perceive varieties of this phenomenon in the manuals, dictionaries and encyclopedias. The few exceptions are manuals of Czesław Lachur and A.Ja. Szajkiewicz and works of Ju. D. Apresjan. 
Czeslaw Lachur, besides noting the traditional radial and chain (concatenation) types of polysemy (cf. Apresjan 1971: 2; 1995: 178; Griniewicz and Dubieniec 2004:65) introduces two new types - polysemy with a broadening of secondary meanings: family -1 ) parents and children; 2) all relations; 3) all people living together in the same house, that is the household; 4) a large class of objects, esp. in biology; and polysemy with narrowing meanings: number - 1) a place in order; 2) size (of boots, etc.); 3) next copy (of newspaper); 4) next performance in a concert; 5) a hotel room (Lachur 2004: 175-176).

A.Ja. Szajkiewicz in a separate chapter devoted to polysemy introduces monocentric polysemy (with one original meaning) and polycentric polysemy, presupposing two or more semantic centres (Шайкевич 2005: 144).

In his works Ju.D. Apresjan conducts a profound analysis of polysemy and introduces a number of new types of this phenomenon. Firstly, on the basis of the way of meaning transfer he discerns between metonymic and metaphorical motivated polysemantism. It should be mentioned that those ways of semantic change in connection with polysemy are discussed in many publications, but without proposing any respective types of polysemy. Moreover, from the point of view of regularity in forming derivative meanings of a certain type he suggests establishing regular (in which the relation between the senses is predictable in that any word of a particular semantic class potentially has the same variety of meanings) and non-regular polysemy or polysemantism (Апресян 1971: 2, 7; 1995: 178, 189-190; Apresjan 1995: 174, 181-204).

Fourthly, in the last 50 years some new aspects of investigating polysemy from the point of view of terminology science, translation theory, terminography, evolution of cognition and human mentality have appeared. As the result of that, new types of polysemy have been discovered.

\section{Polysemy from the point of view of terminology science}

In terminology science the problem of polysemy took a controversial character. In the 1960-70s many terminologists disputed the existence of such phenomena as polysemy in terminology, because, due to strict definiteness of scientific and technical concepts the respective terminological meanings must be also strictly defined and separated. Therefore, in reality we are dealing not with meanings of one and the same term, but with homonymous terms (i.e. terminological form morphology is used in quite different meanings in linguistics, biology and geology). Even in the process of metaphorical formation of a new term, semantic analogy or common characteristics are realised only immediately at the moment of formation of a new term and soon after that are consciously ignored. Usually new terms belong to different terminologies and this promotes alienation of kindred meanings and gaining by respective terms the status of homonyms, i.e. terms glyba in construction (cob, angular stone more than $200 \mathrm{~mm}$ in size) and in pedology (clod 10-200 mm in size), rehabilitation in medicine and law (Grinev 1993: 7; 1994: 52; Гринев-Гриневич 2008: 96-97).

Then it was noticed that in some cases of metaphorical formation of a new term, both terms often stay in the same terminology and their kinship is quite visible. For example, assimilation in linguistics has 2 meanings: 
- Assimilation /1/ - a process of adjusting the articulation of the adjacent sounds that happens between the same types (usually consonants) of sounds.

- Assimilation /2/ - a process of bringing a borrowed word into correspondence with the graphic, phonetic, grammatical and lexical norms of the accepting language.

There are three such cases. Firstly, in creating new terms with the help of metonymic transfer there is a tendency to use names of processes also for the results of these processes e.g. roofing, flooring, carpeting, classification, definition, borrowing, assimilation, isolation, cladding. This phenomenon has a regular character and according to the results of our research in Russian, it happens in 65\% cases (Гринев-Гриневич 2008: 133). In such cases, the old and the new terms exist side-by-side, which is inconvenient.

Secondly, there are cases when the same form is used simultaneously in the broader and the narrower meanings. For example, the term walls in its broader meaning includes partitions, but in a narrow meaning it is opposed to partitions because inner walls carry loads, while partitions do not. In the same way water treatment is divided into mineral water treatment and water treatment proper. Balneology in a broader meaning includes fangotherapy (mud treatment) while in the narrow meaning is opposed to it. In these cases the same form functions as hypernym and hyponym, and situation of hyponymic relation between meanings constitutes hyponymic polysemy.

Thirdly, in a number of cases in the same discipline independently appear terms with the same form and similar meanings: in linguistics we have idiom/1/ (language or dialect) and idiom/2/ (phraseological unit functioning only in a given language) (McArthur 1992), also assimilation/1/ and assimilation/2/. In lexicology we have doublets/1/ (two or more words originating from one source) and doublets/2/ (absolute synonyms).

This leads to hesitations in viewing such cases as homonymy or polysemy and though the former seems to be preferable from the point of view of logic, now in terminological practice, as well as in theory, the second case of using of one and the same lexeme to denote two related concepts within the boundaries of a subject field is considered polysemy.

Thus in terminology, we may find both homonymy and polysemy where in both cases one lexical form is used for naming different concepts. The criterion for discriminating between them in terminology was proposed by V.M. Leichik. If in the process of splitting of the meaning or transfer of the name in the semantic structure of the resulting terms the main seme remains common and the secondary semes differentiate then we have polysemy; if the main seme is different then we have homonymy (Лейчик 1991: 119). This is true for the third case when it is clearly seen that the same form is used to denote similar but different concepts. Additionally at the annual international terminological conference organized in 2011 by the Russian Technical Committee 55 "Terminology" an agreement was reached to regard the transfer of names of processes on the results of these processes as homonymy, since processes and their results belong to different ontological and logical categories.

Thus we may consider the existence in terminology of both homonymy and polysemy as established. The difference between them lies in the fact that in polysemy in the meaning of both terms the common seme is principal, while in homonymy the common seme is secondary. At 
the same time there are types of polysemy which are generally unknown and not yet sufficiently investigated, especially various types of hidden polysemy. Generally speaking we may divide polysemy types into overt (open, explicit) and covert (hidden, implicit) types. The latter may be said to include consubstantibility - the use of the same form in different functional types of lexemes words, terms and proto-terms.

\section{Polysemy in professional translating}

Since the end of the $20^{\text {th }}$ century in translating special vocabulary, numerous cases of the socalled hidden polysemy have been identified, when a term in one language corresponds to two or more terms in another language due to the disparity of national terminologies. Disparity and peculiarities of national terminologies in many cases result from their unrelated autonomous developments. For example, the most popular translation of the Polish term budownictwo is building, which is not always correct because the English term has a much narrower meaning and refers only to building dwellings. It is supplemented by the term civil engineering, which should be used in a number of cases. Historically, the term building was used only with reference to living houses. Everything else built (such as roads, bridges and tunnels, waterworks, etc.) was regarded as engineering. Roads and accompanying artificial structures (such as bridges, tunnels, retaining walls, etc) initially were built for military purposes and, together with defence structures were referred to as military engineering. Some communal buildings and structures as, for example, water supply, sewage system, and waterside structures were the domain of civil engineering. Therefore the Polish term corresponded to two English terms. Finally lately there came into usage industrial structures, large agricultural buildings and irrigation structures, communication structures, main pipelines - that were out of this scheme. Therefore, the term construction appeared, that unites nowadays all kinds of building activities. Thus, in translating we have to pay attention to the proper use of various equivalents (Griniewicz 2010: 80).

\section{Problems of treating polysemy in terminography}

Terminography, which is the theory and practice of compiling terminological dictionaries, is closely connected with translation. We should bear in mind that the dictionary is a main tool of the translator and influences both the quality of translation and the time needed to find the necessary term or to choose between the proposed variants of translating a term. Unfortunately the majority of the present dictionaries have faults and perhaps the most grave is the excess of the variants of translation making the choice of the right equivalent a painstaking job.

For example, in the most popular English-Russian building dictionary (Амбургер 1961) the term aeration is translated as aeracija (the right translation), prowetriwanije (airing, slightly different, narrower term), and ventilacija (ventilation, quite a different term, wrong translation). To the right translation ballast of the term ballast (in railroads) two unnecessary and somewhat wrong translations are added - shcheben' (crushed stone) and gravij (gravel). The term boulder is also translated as bulyzhnik (for which we have the exact equivalent - cobble), gal'ka (for which we have 
the exact equivalent - pebble), and гравий (for which we have an exact equivalent - gravel). In the internet the present situation looks even worse. On the site translate.yandex.ru we find the following variants of translating boulder - valun (the exact equivalent), kamen' (stone - a much broader general concept), glyba (angular stone of the same size, a different concept), bulyzhnik (cobble smaller stones), skala (rock - quite a different concept). The last four variants are erroneous and lead to fallacious translations.

Numerous similar examples of superfluous and erroneous equivalents in English-German German-English special dictionaries were presented in Grinev (1999). I think we may call such practice of supplying unnecessary equivalents creating an artificial polysemy and misleading polysemy in the case of providing erroneous equivalents.

In the domain of professional medicine we also come across artificial polysemy in translating dictionaries. In the Occupational Safety and Health Glossary we find: bezpeczenstwo pracy - occupational safety, industrial safety (the second term is narrower and not an exact equivalent, it is redundant); candidiasis - kandidoz, kandidamikoz; moniliaz; drozhzhevoj mikoz; oidiomikoz; poverhnostnyj blastomikoz (the last 5 terms are exact equivalents, but in the presence of the first, preferable term they are unnecessary and misleading), danger symbol, hazard symbol - preduprezhdajushchij (predosteregajushchij) simvol; znak bezopasnosti; simvol opasnosti - the right Russian term is preduprezhdajushchij znak, while the second variant of translation is a disorienting antonym; inspector truda - labour inspector, factory inspector (the second term is narrower, not an exact equivalent, and therefore redundant); fabrichnaja inspekcija - labour inspectorate, factory inspectorate (here the first variant of translation is a broader term); loss of pigmentation (of the skin), achromy, depigmentation, vitiligo - ischeznovenije pigmentaciji na kozhe - this variant of translation is not a term, while there are accepted terms, i.e. vitiligo; machine guard, guard - zashitnoje ustrojstvo, predohranitelnoje ustrojstvo; ograzhdenije - the second variant is a term denoting quite a different concept. According to our estimates, more than $90 \%$ of the existing translating dictionaries contain excessive and often - misleading translations. Even when the additional translation variants are correct, they induce hesitation; create an illusion of slight differences between the offered equivalents and cause embarrassment of the translator. In our opinion such artificial polysemy is unnecessary and therefore harmful.

\section{The role of polysemy in the evolution of cognition}

Diachronic investigation of terminologies has led to the discovery of one more type of hidden polysemy - multitemporal (or diachronic) hidden polysemy, taking the form of semantic syncretism. In a number of cases the original meaning was quite dissimilar from the modern one - the analysis of the basic terms of emotion showed that in many cases the initial meaning was different. In some cases it firstly named the cause of emotion: wonder - something causing surprise; fear danger, grief - something causing suffering; anger - something causing pain or irritation, distress - stress, fun - practical joke. 
It was also found that in the history of human evolution there is hidden fused polysemy in the semantic characteristics of the early word-stock. We can find rich evidence of loose bunches of meanings in old languages or old stages of modern languages. One of the remarkable features of Anglo-Saxon words is the diversity of meanings included in their semantic structure, e.g. beodan - to bid, command, proclaim, offer, give; blip - joyful, merry, gentle, kind, sweet, calm; brucan - to use, enjoy, eat, employ. In many cases the meaning of an Anglo-Saxon word encompasses many present-day notions, e.g. aldor - life, age, parent; cynn - a sort, kind, race, family, nation; cyst - choice, election, what is chosen, excellence, virtue, goodness; croft - power, might, art, skill, trade, knowledge, cunning, any kind of ship; feoh - cattle, money, value, fee, reward, property; rün - whisper, mystery, secret, letter; talu - tale, story, talk, account.

From the modern point of view, the next remarkable feature of initial polysemy is combining hardly compatible meanings, e.g. feolah - to cleave, stick, adhere, to reach, come, pass; dreorig bloody, sorry, sorrowful, cruel, wounded; $d u g u ð$ - manhood, multitude, glory, power, advantage, prosperity. Sometimes it even takes the form of enantiosemy: dreogan - to do, to work, to perform, to endure, to suffer; to enjoy; gretan - to welcome, to bid farewell.

There are reasons to believe that what we now describe as polysemy in old languages took the shape of vagueness of meaning based on the absence of differentiation between notions which are quite different from the present-day, but which are somewhat similar or may have something in common. In many cases we may observe the absence of stable borders of meanings of an old word such as in the following OE words: dōm - judgement, decree, law, command, power, dignity, free will, choice; lāp - something hateful, something harmful, something evil, injury, grief, pain, enmity; searo - device, design, craft, artifice, arms, equipment.

In some cases the meaning of an Old English word points to a certain general idea underlying particular meanings: ansyn - face, countenance; sight, form, figure; beah - ring, bracelet, collar; flota - ship, fleet, sailor; facen - deceit, evil, crime; greot - sand, dust, grit (Griniewicz 2007: 39-41). Commenting on polysemy of Old English words one of the investigators concludes that it is practically impossible to differentiate between the meanings even with the help of the context, because we are dealing here rather with a broad meaning combining into dissoluble whole notions which are quite diverse for the present-day reader (Добрунова 1980: 9). We may suspect that what we now apprehend as polysemy of the majority of words was not viewed as such by the contemporary speakers. Perhaps they did not see the need to differentiate between the kinds of a notion they had not yet fully investigated.

\section{Conclusions}

As a result of recent advancement in a number of directions of linguistics the number of the known types of polysemy has grown and may be organised into the following tentative classification: we start with dividing polysemy into overt (explicit, open) and covert (implicit, hidden) polysemy.

The first may be further subdivided (on the basis of ways of formation) into metaphoric and metonymic subtypes, and also (on basis of the character of development) into radial polysemy 
(when the primary meaning stands in the centre and the secondary meanings proceed out of it like rays) and concatenation or chain polysemy (when secondary meanings of a word develop in succession like a chain). The same category comprises systematic (or regular) polysemy, in which the relation between the senses is predictable in that any word of a particular semantic class potentially has the same variety of meanings. In terminology we find polysemy with hyponymic relation between meanings of a term that may be called hyponymic. To these varieties of polysemy we should add the well-known in linguistics enantiosemy - combining the opposite meanings in one word, “'...enantiosemy, the presence of polysemies in which one sense is in some respect the opposite of the other" (Traugott 2006: 129). Examples are: scan - 1) careful observation from point to point; 2) cursory glancing from point to point; eye - 1) to look at sth (ice-cream) with desire; 2) to look coolly. Traditionally it is viewed as antonymy (cf. Новиков 1990: 36).

To the covert polysemy belong interlingual polysemy (monosemic word having several meanings in a different language) and diachronic polysemy (almost every old word used to have several meanings).

Strictly speaking, since man began to form ideas about the surrounding world and to find words to name those ideas, eliminating hidden polysemy of initial words has been the most effective means in forging a better understanding of the world we live in, as well as ourselves. Removing such hidden diachronic polysemy contributes to enhancing our cognition, to the development of science and to the evolution of the human mind. However accurate and precise we may view meanings of words (even terms) belonging to the present-day vocabulary, there is no guarantee that in the next century they (or at least some of them) will not be perceived as inexact and ambiguous. Perhaps one of the essential characteristics of human knowledge growth and anthropogenesis in general is an eternal quest for the elimination of polysemy.

\section{References}

Apresjan, Jurij D. 2000. Semantyka leksykalna. Synonimiczne środki języka. Wrocław: Ossolineum. Buttler, Danuta. 1987. Język i my. 2. Podręcznik do jezyka polskiego dla klasy II szkół średnich. Warszawa: WSIP.

Encyklopedia języka polskiego. 2nd ed. 1994. Ed. by S. Urbańczyk. Wrocław: Ossolineum. Encyklopedia językoznawstwa ogólnego. $2^{\text {nd }}$ ed. 1999. Ed. by K. Polański. Wrocław: Ossolineum.

Grinev, Sergej.V. 1993. Terminology Research in the Former USSR, Selected Readings in Russian Terminology Research. Wien, 2-12.

Grinev, Sergej V. 1994. Theoretical Foundations of Russian Terminology Work: Peculiarities and Perspectives, Applications and Implications. Current LSP Research. Vol.1. Bergen, 49-56.

Grinev, Sergej V. 1999. On the Principles of Improving Translating Terminological Dictionaries, Stupskie Prace Humanistyczne 18a, 95-105.

Griniewicz (Grinev), Sergej. 2007. "Eliminating indeterminacy: Towards linguistic aspects of anthropogenesis". In: Antia, Bassey (Ed.), Indeterminacy in Terminology and LSP, Amsterdam/ Philadelphia: John Benjamins, 37-48. 
Griniewicz, Sergiusz. 2010. On terminological problems of translation, Edukacja dla Przyszłości. vol VII, Białystok, 79-84.

Griniewicz, Sergiusz W., Dubieniec, Elwira M. 2004. Introduction to Linguistics. $2^{\text {nd }}$ ed. Białystok: WSFiZ.

Jackson, H., Amvela E. Z. 2007. Words, Meaning and Vocabulary: An introduction to modern English lexicology. $2^{\text {nd }}$ ed. London/New York: Continuum.

Koskela, A. and Murphy M.L. 2006. Polysemy and Homonymy. In: Encyclopedia of Language and Linguistics 2 ed. Elsevier Ltd.

Lachur, Czesław. 2004. Zarys językoznawstwa ogólnego. Opole: Wydawnictwo Uniwersytetu Opolskiego.

Lyons, John. 1976. Wstęp do językoznawstwa. Warszawa: PWN.

Malczewski, Jan. 1993. Szkolny słownik nauki o języku. Warszawa: BGW.

McArthur, Tom. 1992. The Oxford Companion to the English Language. Oxford: Oxford University Press.

Miodunka, Władysław. 1989. Podstawy leksykologii i leksykografii. Warszawa: PWN.

Occupational Safety and Health Glossary.1993. International Occupational Safety and Health Information Centre (CIS).

Ten Hacken, P. Indeterminacy in terminology and LSP: a Review. Retrieved from http://linguistlist.org/pubs/reviews/get-review.cfm?SubID=173870

Traugott, Elizabeth Closs. 2006. Semantic Change: Bleaching, Strengthening, Narrowing, Extension. Encyclopedia of Language and Linguistics. Elsevier Ltd., 124-131.

Weinsberg, Adam. 1983. Językoznawstwo ogólne. Warszawa: PWN.

Алефиренко, Н.Ф. 2007. Теория языка. Вводный курс: учеб. пособие для студ. филол. спец. высш. учеб. заведений. 2-е изд., испр. и доп. Москва: Академия.

Амбургер, П.Г. 1961. Англо-русский строительный словарь. Москва.

Апресян, Ю.Д. 1971. О регулярной многозначности. Известия АН СССР. Отделение литературы и языка. Т. ХХХ. Вып. 6. Москва, 509-523.

Апресян, Ю.Д. 1995. Избранные труды, том І. Лексическая семантика (синонимические средства языка). Москва, Издательская фирма “ВОСТОЧНАЯ ЛИТЕРАТУРА” РАН

Вендина, Т.И. 2002. Введение в языкознание: Учеб. Пособие для педагогических вузов. Москва, Высш.шк.

Ганеев, Б.Т. 2001. Язык. Учебное пособие. 2-е изд., переработ., доп. Уфа, Изд-во БГПУ.

Головин, Б.Н. 2005. Введение в языкознание. Изд.5-е, стереотипное. Москва, Едиториал УРСС.

Гринев, С.В. 2001. Разновременная скрытая многозначность.Научно-техническая терминология. Вып.2. Москва, 37-39.

Гринев-Гриневич, С.В. 2008. Терминоведение: учеб. пособие для студ. высш. учеб. заведений. Москва: Издательский центр “Академия”.

Елисеева, В.В. 2003. Лексикология английского языка (учебник). СПб: СПбГУ. 
Ефремова, Т. Ф. 2000. Новый словарь русского языка. Толково-словообразовательный. Москва: Русский язык.

Кондаков, Н.И. 1976. Логический словарь-справочник. Москва.

Крысин, Л.П. 2008. Толковый словарь иноязычных слов. Москва: Эксмо.

Лейчик, В.М. 1991. Семантическая омонимия и многозначность в сфере терминов, Лексика и лексикография. Москва, 115-121.

Лингвистический энииклопедический словарь.1990. Советская Энциклопедия.

Маслов, Ю.С. 1987. Введение в языкознание: Учеб. для филол. спеи. вузов. 2-е изд., перераб. и доп. Москва, Высш. шк.

Новиков, А.И. 1990. Антонимы. Лингвистический энциклопедический словарь. ред. В.Н. Ярцева. Москва. http://tapemark.narod.ru/les/

Ожегов. С.И. 2008-2009. Толковый словарь Ожегова онлайн - dic.academic.ru .

Полисемия in: ru.wikipedia.org

Полисемия in: translate.yandex.ru

Реформатский, А.А. 1996. Введение в языковедение. Москва: Аспект пресс.

Степанов, Ю.С. 1975. Основы общего языкознания. Изд.2-е. Москва: Просвещение.

Фомина, М.И. 1978. Современный русский язык. Лексикология :Учебник для студентов интов и фак-тов иностр. яз. Москва: Высш. школа.

Шайкевич, А.Я. 1995. Введение в лингвистику. Москва: Изд-во Российского открытого ун-та. Энциклопедия “Русский Язык”. 1997. Караулов Ю.Н. Издательство: Москва: Дрофа 